University of Nebraska - Lincoln

DigitalCommons@University of Nebraska - Lincoln

2-10-2022

\title{
Ten Nights' Dreams and Our Cat's Grave
}

Natsume Soseki

Follow this and additional works at: https://digitalcommons.unl.edu/zeabook

Part of the Japanese Studies Commons, Modern Literature Commons, and the Translation Studies Commons

Recommended Citation

Soseki, Natsume, "Ten Nights' Dreams and Our Cat's Grave" (2022). Zea E-Books Collection. 119. https://digitalcommons.unl.edu/zeabook/119

This Book is brought to you for free and open access by the Zea E-Books at DigitalCommons@University of Nebraska - Lincoln. It has been accepted for inclusion in Zea E-Books Collection by an authorized administrator of DigitalCommons@University of Nebraska - Lincoln. 


\section{Ten Nights' Dreans \\ $\mathcal{q}$ \\ Our Cat's Grave}

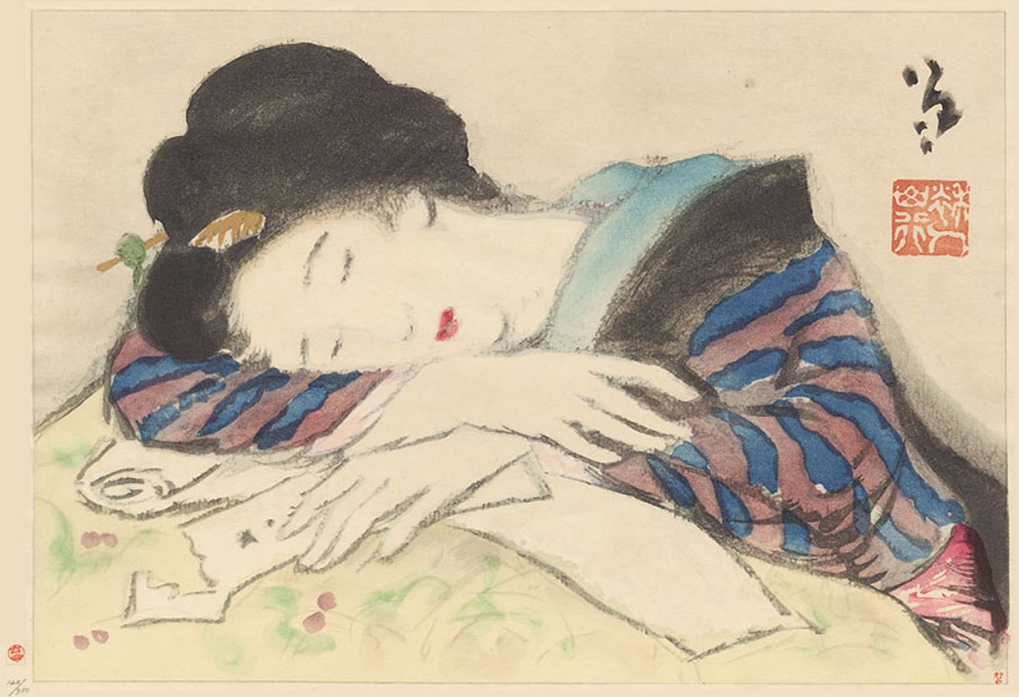

Natsume Soseki 
Ten Nights' Dreams (夢十夜, Yume Jüya) is a classic written work from the Japanese master Natsume Soseki. Originally published in 1908, it announced the emergence in Japanese literature of a modernist and impressionistic mode. Short vignettes with fantastic, tragic, or magical events convey an exquisite sensibility compounded with stark realism. Love, honor, duty, artistry, desire, despair, and regret all shape events in the dream-world. The stories themselves suggest echoes of meanings beyond the failures of rational sense-making. Ten dreamseach unique and arresting - form a panorama of life and feeling, at once universal and intensely present.

"Our Cat's Grave" is a brief but heartfelt monody for a feline companion. Encompassing both the affection and the neglect, it becomes a meditation on empathy and helplessness, and on the transience of life and the persistence of memory.

Cover illustration by Takehisa Yumeji.

Zea Books

Lincoln, Nebraska

ISBN: 978-1-60962-238-1

DOI: 10.32873/unl.dc.zea.1319 


\section{TEN NIGHTS' DREAMS}

AND

OUR CAT'S GRAVE 


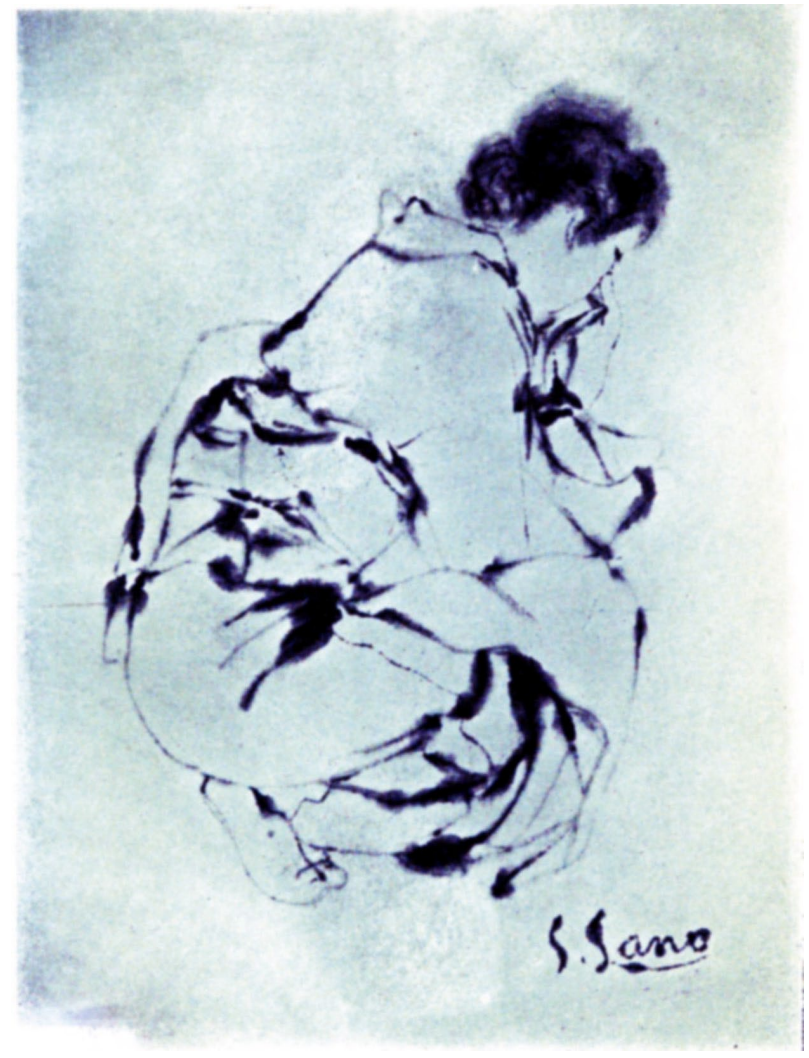




\title{
TEN NIGHTS' DREAMS
}

AND

\section{OUR CAT'S GRAVE}

BY

\section{NATSUME SOSEKI}

\author{
TRANSLATED BY \\ SANKICHI HATA \\ AND \\ DOFU SHIRAI
}

FRONTISPIECE BY

SHIGEJIRO SANO

ZEA BOOKS

LINCOLN, NEBRASKA

2022 
First published 1934 by Tokyo News Service, Ltd., Tokyo, Japan

ISBN 978-1-60962-237-4 paperback ISBN 978-1-60962-238-1 ebook doi:10.32873/unl.dc.zea.1319

Zea Books are published by the University of Nebraska-Lincoln Libraries.

Electronic (pdf) edition available online at https://digitalcommons.unl.edu/zeabook/

Print edition available from Lulu.com at http://www.lulu.com/spotlight/unllib

UNL does not discriminate based upon any protected status. Please go to http://www.unl.edu/ equity/notice-nondiscrimination 


\section{Contents}

Translators' Note, Sankichi Hata \&

Dofu Shirai . . . . . . . . . . . . . .7

A Reader's Note, H. Vere Redman . . . .99

In Lieu of a Preface, Toyotaka Komiya 13

Ten Nights' Dreams

First Night . . . . . . . . . . . . 17

Second Night . . . . . . . . . . 23

Third Night. . . . . . . . . . . 31

Fourth Night . . . . . . . . . . 37

Fifth Night . . . . . . . . . . . 43

Sixth Night . . . . . . . . . . . 49

Seventh Night. . . . . . . . . . 57

Eighth Night . . . . . . . . . . 63

Ninth Night. . . . . . . . . . . 71

Tenth Night. . . . . . . . . . . 79

Our Cat's Grave . . . . . . . . . . 85 



\section{TRANSLATORS' NOTE}

In translating a few of Natsume Soseki's short stories into English, we have tried as best we could to retain the largest measure of the spirit and style of the Japanese original. Natsume Soseki was one of the greatest men of letters Japan has produced since the Meiji Restoration of 1868 . He was born in 1867 and died in 1916 in Tokyo, leaving a splendid literary legacy. It is impossible adequately to describe the life and achievements of such a great author in the limited compass of this note. It should be said, however, that what we offer in English within the scope of this slim volume represents but a few bricks in the stately literary edifice left behind by Natsume Soseki.

We are indebted to Mrs. Natsume for giving us permission to translate the stories contained in this book, to Prof. Toyotaka Komiya of the Tohoku Imperial University for obtaining this permission for us and 
contributing the appreciative letter which follows, and to Mr. John Eills and Mr. H. Vere Redman for reading the manuscript of the translations.

Sankichi Hata

Dofu Shirai

Tokyo, October 30, 1934 


\section{A READER'S NOTE}

The stories which follow are not easy reading for the occidental who would be sure he knows what he has read. Bacon's assertion that knowledge is power means more than "with this much known we can control this or that much of our environment." There is, indeed, both instant and resultant power in the application of knowledge, but the profoundest sense of power comes surely with the consciousness of its possession. The frequently heard question among litterateurs: "Do you know this or that book?" contains a gesture towards that sense of power. It is not: "Have you read the book?" It is not: "Have you enjoyed it?" It is rather: "Are you sure that what is there is now really, yours, that the adventure has finished with conquest, and with the conquest has come power?" No occidental will know Soseki in that sense. There are indeed few Japanese who do. This is, of course, another way of 
saying that he is an elusive writer. But his elusiveness has a quality all its own. Elusive writing in general can be divided into two categories, the one bearing the badge of enigma, the other that of fantasy. Soseki has evidently some taste for enigma and a rare exuberance of fantasy; but, as these stories seem clearly to illustrate, he is not definitely enrolled under the banner of either. Enigma may lurk in this or that story, and fancy is free in all. But just when the imagination is most riotous, the key of an enigma may be revealed, and just when the stage seems set for parable the writer, with what looks very much like a wink, decides simply to let purposeless fancy take wing.

Thus the determined reader may be uneasy. But he will be compensated for his unease by constant charm both of phrase and situation. Soseki, whether dealing in fantasy pure or fantasy tinged with enigma, deals often in humour and always in beauty. The colours of flowers, skies and seas, the lines of the pine-tree, the nearby human form, or the distant hills, are ever present in his consciousness, and these he communicates, whatever kind of human values may be momentarily engaging him. 
Of these "dreams," it can also be said that they are authentically of "such stuff as dreams are made on." The dream world is credited with being vaster than the one of here and now, but conventionally it would seem more circumscribed. It embraces the heavens but neglects much of earth; includes the extraordinary but excludes the ordinary. Soseki triumphs over this convention and produces a barber who is as authentic a denizen of dream land as the love-driven Amazon galloping through the night, or the dying maiden who promises to return as a star.

I have purposely refrained until this my last paragraph from saying anything about the fact that Soseki was a Japanese. This, apart from being obvious, is, it seems to me, not of immense importance. He has certain Japanese characteristics and his scenes and characters are of course Japanese too. Some of the latter are indeed the most obvious of stage props in the Japanese literary paraphernalia, notably the Samurai in the second night's dream. But his images are his own, as are his cumulations of apparently irrelevant detail to create a desired atmosphere. And, by and large, what is much 
more important about Soseki than his nationality is his personality. However, it must be conceded that the reader of these stories will learn something of Japanese literary methods as of Japanese literary taste. This will justify the excellent work of the translators to the many worthy people in all lands who regard literature as a series of national exhibitions. For my part, I feel that the work is justified by the intrinsic value of what has been translated, and I feel confident that there are many Western readers who will share this view.

\section{H. Vere Redman}

Kamakura, Sep. 7, 1934 


\section{IN LIEU OF A PREFACE}

My dear Mr. Hata and Mr. Shirai,

I have just finished reading your translations of Yume Juya (Ten Nights' Dreams) and Neko no Haka (Our Cat's Grave). As for your request for me to write a preface to them, I wish to refrain from saying anything so far as your translations are concerned as such, because I have never made a special study of the English language.

Quite a number of Professor Natsume's works have been translated into English, German, French, Russian and other foreign languages. But as far as I know, whenever the professor received a letter asking for permission to translate any of his stories, he used to decline the request on the ground that his work was not worth translating or that its style did not suit translation.

In fact, his earlier stories such as Genei no Tate, Kairoko, Kusa-makura and Gubijinso are, in my opinion, written in a peculiar 
style making it impossible to translate them into any foreign tongue with any fidelity to the original. However, the professor's style became more and more natural in later years. This is probably why he used to say that if some of his work had to be translated the later stories would be more suitable. But the professor seems to have been induced to consent to have Yume Juya translated in spite of the fact that it was among his earlier works. Thus a very brief section of Yume Juya was translated and published together with some other translated stories, if I remember rightly. Yume Juya is a series of short stories and the style is comparatively simple. Moreover, the world of imagination dealt with is mainly of a universal nature, being neither distinctively occidental nor distinctively oriental. I imagine this is why the professor did not persist in declining permission to translate the series.

Generally speaking, the shorter pieces of the professor's work seem to have something in them easily comprehensible by occidental readers even when rendered into a foreign language. Being one of such shorter pieces, I think Neko no Haka should 
be sure of Western appreciation. I should like to know, however, if the description of the Buddhist meditation in a Zen sect temple in the Second Night's Dream, that of a man walking with a child on his back in the Third Night's Dream, or any other such dream in Yume Juya will appeal to the occidental readers in the same way as it does to us. Again, in Neko no Haka, will occidentals appreciate the seventeen-syllable verse, "Kono shitani, inazuma okoru yoi aran," written on the grave of the cat, as much as we do? I am anxious to hear the frank opinions of occidental readers of the translations of this verse. Such expressions of opinion will serve to reveal the differences of sentiment between the two races.

Another thing which occurred to me while reading your translations is the fact that some Japanese expressions can be rendered into English literally, while others must be rewritten in order to be intelligible. In the latter case, the English translations strike us as something altogether different from the original, although this probably cannot be helped when translating one language into another of which the structure is 
completely different. It is interesting, however, to note that such translations sometimes serve to set off some peculiar beauty of expression remaining unnoticed in the Japanese texts, with a suddenly added brilliancy. Struck by such beauty, I would turn back to the original and find it there too, though it had thitherto escaped my notice. I owe it to your translations that I have newly discovered a number of instances of the beauty of literary expression in Professor Natsume's work, which I had hitherto failed to appreciate fully.

Yours truly,

Toyotaka Komiya

Sendai, August 21, 1934

Note: -

Prof. Komiya was one of the most trusted students and friends of the late Professor Natsume. 
THE FIRST NIGHT 


\section{THE FIRST NIGHT}

\section{CUCH was my dream: -}

$\mathcal{W}$ With folded arms, I was sitting beside my pillow, when a woman lying there, her face upturned, said in a gentle voice that she would soon die. Making a pillow of her long tresses, she looked up from among them, and the contour of her face, shaped as a melon-seed, was all grace.

The snow white of her white cheeks was tinged with the warm colour of blood, while her lips were fully red. Death, indeed, seemed far from her. Yet softly, she murmured distinctly that she would soon die. Then I too shared her thought. So I said, "Well? Are you going to die now?", looking down into her face as I spoke. "I am sure I shall die." So saying, she opened her eyes wide. They were bright eyes, moist, and black all over, shut in with long lashes. In their deep black pupils was clearly mirrored my form. 
Gazing at the brightness of the pupils which looked so transparently deep, I again doubted if she was really about to die. Whereupon, putting my mouth near her pillow, I asked again, "You are not dying, are you? Not dying? You are quite sure of it?" Thereupon, drowsily holding her black eyes wide open, she said gently, "But I am going to die. There is no help for it."

"Then," I asked intently, "can you see my face?"

"Can I see your face? There, you see, it is reflected, isn't it?" So saying, she smiled. Without asking further questions, I raised my face from her pillow. I folded my arms and thought again her end was near.

After a while she said, "When I am dead, please bury me. With a big pearl oyster shell dig a grave. And with a broken piece of a fallen star put up a grave-post. And then please wait beside my grave. I will come again to you."

I asked when she would come.

"The sun rises, you know, then it sets. Then it rises again, and sets again, you know... While the red sun passes from east to west, continually ... will you be patient enough to wait for me?" 
Silently I assented with a slight movement of my head. Then, raising her gentle voice just a little higher,

"Please wait a hundred years," she exclaimed resolutely.

"For a hundred years, wait beside my grave, please, as I shall not fail to come to you."

I only replied that I would wait.

And just then, the reflection of myself, clearly seen in her black pupils, began to lose its shape. It swung like a shadow on the gently-ruffling surface of still water. The eyes of the woman suddenly closed. From between her long eyelashes tears gently flowed down her cheeks. She was dead.

Then I went down to the garden and dug a hole with a pearl-oyster shell. It was a big shell with a smooth and sharp rim. Every time I scooped up earth, the back of the shell sparkled in the moonlight. There was also a smell of damp soil. Soon a grave was dug. I laid the body of the woman in it. And I gently covered it with soft earth. Every time I replaced the earth, in the back of the pearl-oyster the moonlight sparkled. Then I brought a chip of a star and put 
it lightly on the spot where her body was buried. The fragment of the star was round. As it had taken a long time shooting down through space, its corners were rubbed off, and it had so become smooth, I thought. As I was carrying it to its place above the grave, my breast and hands were slightly warmed.

I sat down upon some moss. Thinking that I now would have to sit in this way and wait for a hundred years, I folded my arms, and watched the round gravestone. In the meantime, the sun rose, as she had said. It was a big red sun, and big and red it set. This was but natural, yet to me it seemed that the sun had risen and set because she said it would.

One ! I counted.

It was not long afterwards that the crimson sun slowly rose again. And it silently sank. Two I counted.

So many times the red sun passed above my head that at length I could count no more. And yet the hundredth year did not come. At last, watching the round stone now clothed in moss I began to doubt whether the woman had not deceived me. 
And just then from under the stone a green stalk began to grow obliquely towards me. In a twinkling, it grew up, and stopped when its top just reached my breast. A slender bud, slightly inclining its head at the top of the nodding stalk, gently opened, and a white lily under my very nostrils smelled so sweet that its perfume penetrated to my bones. From far above my head, a dew drop fell, and the flower drooped slightly under its weight. Leaning forward, I kissed the white petals dripping with cold dew. Withdrawing my face from the lily I looked up to the distant sky where the morning star was twinkling in solitude. "The hundredth year has now come!", my spirit said with certainty and appeasement. 
THE SECOND NIGHT 


\section{THE SECOND NIGHT ${ }^{(1)}$}

\section{SUCH was my dream:-}

5 Leaving Osho' $\mathrm{s}^{(2)}$ chamber in the temple, I came along a passage and returned to my room, and found a paper-shaded nightlight dimly burning there. With one knee resting on a cushion, I enlivened this rushlight, and all of a sudden the snuff thereof fell upon the lacquered stand like a wilted flower.

The room suddenly grew light. The picture upon the paper sliding-doors had been drawn by the brush of Buson. It was a picture of black willow-trees growing thickly here and thinly there, with a lone fisherman, wearing his bamboo-hat on one side, hurrying along the bank of a stream. In the toko or alcove there was hanging a scroll by Kaichu Monju. The remains of an incense-stick were still smouldering in the dim corner of the room. As it was a large temple, all was silent and deserted as in a 
graveyard. As I looked upward, the round shadow cast upon the black ceiling by the paper night-light seemed to have a life of its own. With one knee raised I turned up the cushion with my left hand and, putting my right hand beneath, I found ... it was where I thought it would be. As it was there, I felt relieved. I replaced the cushion and sat down.

If you are a samurai," Osho had said, "it is not possible that you cannot comprehend." "Seeing that you are unable to comprehend for so long a time," he had continued, "I do not think you are a samurai." "You are of the scum of human beings." "Oh, you are offended," he had said laughing. "If you are resentful, give me some evidence that you have understood." So saying, he had turned his face away, showing his back to me. An impudent man he was.

By the time the clock in the toko in the adjacent hall strikes the next hour I shall surely comprehend. After I have understood, I will enter Osho's room again tonight. And I will exchange my comprehension for Osho's head. Unless I comprehend I shall not be able to take his life. By heaven 
and earth, I will comprehend I am a samurai. If I should not be able to comprehend, I will kill myself with my own sword. Disgraced, a samurai cannot cling to life. I will die like a man.

When I was thus resolved, my hand involuntarily slipped under the cushion and dragged out a dagger encased in a cinnabar-scabbard. I gripped the hilt of it and shook the scabbard off, and the cold blade flashed in the dark room. The eerie thing looked as if fleeing from my hand. It was finely sharpened at the end and all my ferocity and thirst for blood rushed forth to its keen point. Looking at this sharpedged weapon with its needle-like head, I all at once felt eager to thrust deep its full 10 inches. The blood of my whole body flowed down towards the wrist of my right hand and made the hilt damp with sweat. My lips were trembling.

Sheathing the dagger and drawing it close under my right arm, I sat crosslegged. Choshu ${ }^{(3)}$ says, "nothing." What is "nothing?" Confound that priest! I gnashed my teeth.

The hot breath gushed from my nose. 
My temples were convulsed and painful. I opened my eyes to twice their ordinary size.

There came into sight the hanging scroll, the paper-framed night-light, the mats. Osho's bald head was acutely visible. I could even hear the voice with which he had scornfully laughed at me, opening his cavernous mouth. The Devil take him! By heaven and earth I will get his bald head in exchange for my comprehension. I will comprehend. "Nothing, nothing," I growled at the root of my tongue. In spite of "nothing" (I had to know the truth of "nothing") I could still smell the incense-stick. What an irritating thing for a joss-stick to give forth smell!

All of a sudden I clenched my fist and struck my own head quite hard. I ground and gnashed my teeth. I sweated at the arm-pits. My back became stiff as a rod. I suddenly felt a pain in my knee-joints. I resolved that I did not care whether my knees should break or not. But it was painful and tormenting. "Nothing" was apparently far from me. When I thought it would come, I at once felt pain. I became indignant and regretful. I felt exceedingly mortified. Tears 
rolled down my cheeks. I wished I could knock my body against a large rock and dash it to pieces.

Thus impatiently, I sat there. Yet I managed to endure this insufferable thing in my mind, as it entered into the muscles of my body and, growing impatient, tried to rush out through the pores of the skin, but all the ways were clogged up, no outlets were discovered. In such a merciless condition I was.

In the meantime, my brain grew strange. The consequence was, that the papershaded night-light, the picture by Buson, the mats, the shelves arranged like steps, looked as though they were not where they really were, or as if they were where they were not. Yet "nothing" did not make its appearance at all. Evidently I must have been sitting without conviction. Then the clock tinkled in the next room.

I was startled by this. I put my right hand upon the hilt of the dagger. Another tinkle from the clock! 
Note:-

1. The experiences here described are those of a person engaged in the Zen Buddhist practice of meditation. The meditator is presented by the priest with a problem, which he must solve without resort to ratiocination by a process of spiritual attunement. In the instant case he has evidently been asked to realize and comprehend negation. Thus each manifestation of his consciousness of the physical world is an added torment, for it reminds him that he is still remote from his goal.

2. Osho is the title of a Japanese Buddhist priest.

3. Choshu is the Japanese pronunciation of a Ghaochow, a Chinese philosopher (778-897). 

THE THIRD NIGHT 


\section{THE THIRD NIGHT}

$S_{\text {A boy, six years of age, was riding }}$ on my back. Doubtless it was my son. The only thing I could not account for was that all unknown to me his eyesight had been lost and his head cleanly shaven. When I asked him when he lost his eyesight, he replied, "Well, it was a long time ago." His voice was unmistakably that of a boy, but his manner of speaking was exactly that of a grown-up man, and my equal as a man at that. On either side of the narrow road were green paddy-fields. From time to time, the fleeting figures of herons could be seen in the gathering darkness.

"Now we are come to the rice-fields, aren't we ?" said the rider on my back.

"How can you tell that?" I asked, turning my face backward.

"Why, we can hear herons screaming," he replied. 
And thereupon, herons were really heard crying, twice or so.

My son being as he was, I began to dread him a little. With such a boy on my back, I thought, some ill will befall me. Thinking where I should desert him, I looked far into the night and saw a large grove. It was just at the very moment when I thought the grove would be an ideal place to abandon him, that from my back I heard a sound of gentle mockery.

"What are you laughing at?"

The boy did not reply, but merely asked, "Am I heavy, Father ?"

"No," I replied.

"Ere long you will find me heavy," he said.

In silence I walked on, heading for the grove. The road through the rice-fields meandered irregularly and I could not reach the destination as I wished. After a while I came where the road forked off. I stood at the junction of the forked road and took a rest.

"There must be a stone standing here," cried the boy.

Sure enough, there was a stone with equal sides, of eight inches, standing as high as my waist. On the face of it there were 
inscriptions - "Left-Higa-Kubo" and "RightHotta-Hara." It was all dark, but the words inscribed were distinctly seen. The red inscriptions were seemingly of a colour like that of the water-lizard. (A Japanese waterlizard or eft is usually dark all over its body, except for its belly having red mottles.)

"To the left is better, I suppose," the boy advised. I looked to the left and there the grove was casting its dark shadow over our heads from the high sky. I hesitated.

"You need not hesitate," said he. I began to walk towards the grove. Wondering in the recesses of my heart how he knew so well in his blindness, I continued to walk along the straight road, and as I approached the grove, the voice from my back said, "How sorely my blindness tries me!"

"That's why I am carrying you on my back," I replied.

"I must thank you for carrying me, but everybody makes a fool of me. Even Father makes a fool of me. That's what I hate."

I felt a strange distress. Thinking I would go fast to the grove and abandon him, I hurried on.

"When you go a little further, you will come to understand-It was on just such 
a night as this," said he on my back, as if he had been talking to himself. "What?" I asked in a sharp tone. "What? You ought to know all about it," said the boy scornfully. Then, I began to feel I had known, but could not remember exactly. Only I felt it must have been on such a night. And I felt that all would become clear to me when I had gone a little further. If, however, I should remember, the memory might prove to be an awful thing for me. So before summoning my memory I felt I must relieve myself of his presence, and I quickened my pace the more.

Rain had been falling for some time. Gradually the road became dark. Practically I did not know where I was. Only on my back a little boy clung closely to me, and the little boy, reflecting all my past, present and future, gleamed like the most relentless of mirrors that searches out the smallest facts. And he was my boy at that. And he was blind. I was in infinite distress.

"Just here, it was just here. Just at the root of that cedar."

Amidst the sound of the falling rain the boy's voice was distinctly heard. Involuntarily I stopped. Without my knowing it, we were already in the grove. About six feet 
ahead there was some thing black which, as the boy said, seemed to be a cedar-tree.

"Father, it was at the root of the cedar, was it not?"

"Yes, it was," unconsciously I replied.

"The fifth year of the Bunka era, the year of the Dragon, I suppose."

Perfectly naturally I felt that it had been the fifth year of the Bunka era, the year of the Dragon.

"It was just a hundred years ago that you killed me, was it not?"

As soon as I heard him say this, the consciousness that a hundred years back in the fifth year of the Bunka era, the year of the Dragon, on a dark night like this, at the root of the cedar I had killed a blind man, suddenly came to me. And just then, when I realized I had been a murderer, the boy on my back became all of a sudden as heavy as a stone image of Jizo. ${ }^{(1)}$

\section{Note:-}

1. Jizo is a guardian deity of children. His images, usually of stone, are frequently used as symbols of heaviness in Japanese literature. 
THE FOURTH NIGHT 


\section{THE FOURTH NIGHT}

T $\mathrm{N}$ the centre of the earthen floor of a large 1 room there was a sort of bench for enjoying the evening cool surrounded by small tabourets. The bench gave forth a black lustre. In a corner, with a small square diningtable before him, an old man was helping himself to saké. With the wine he was apparently eating some sort of relish.

The old man was aglow from his drink. Moreover, his whole complexion was bright and his face had hardly any wrinkles. Yet his moustache was white, and it was clear to me that he was an aged man. Boy as I was, I asked my little self how old he could be. Just then a good woman brought in a pailful of water from the water-pipe at the back of the house, and wiping her hands with her apron, asked:

"How old are you, Ojii-san?"(1)

The old man, setting down the relish which he was putting into his mouth, said 
unconcernedly, "I have forgotten how old I am." The woman was standing with her hands between her obi, looking at the old man's profile. From a sort of big tea-cup the old man drank his sake at a draught and exhaled a long breath through his moustache. Then the woman asked.

"Where is your house, Ojii-san?" The old man paused in his deep breathing and said, "Why, in the depth of my navel."

The good woman, still with her hands between her obi, asked,

"Where are you going?" Then the old man, again drinking his hot saké at a gulp, and exhaling a long breath as before, said, "Over there."

"Straight ahead?" When the good woman asked this, the breath he emitted passed off through the shoji, (2) and passing under the willow-tree, went straight towards the river bank.

The old man went out of the house. At his waist a small gourd was hanging. From his shoulder a square box hung under his arm-pit. He was dressed in tight-fitting trousers of light blue and a sleeveless coat to match. His tabi ${ }^{(3)}$ were yellow. They were seemingly made of leather. 
He went straight out under the willowtree; where there were three or four children. With a smile, he took from his waist a light blue towel, which he twisted lightly till it was as thin as paper string and put on the ground. Then he drew a circle round the towel. Finally, from the box hanging down from his shoulder he took out a flute made of brass, like that of an ameya. ${ }^{(4)}$

"By and by this towel will become a snake. Watch it. Watch it," he said repeatedly.

The children watched it quite intently. I too was watching it.

"Watch it. Watch it. Are you watching?" So saying and piping on his flute, he began to move round the circle. But the towel did not make the slightest movement.

Vigorously the old man blew his flute. And he went round the circle several times. Stepping cautiously on the tips of his strawsandals, and as if to avoid touching the towel round and round he went. He looked as one afraid yet joyful.

Suddenly he stopped playing his flute. He opened the box hanging down from 
his shoulder, and picking up the end of the towel, he threw it into the box.

"When it is put in the box like this it will turn into a snake. I'll show you soon. I'll show you in a minute." So saying, the old man began to walk on. Passing under the willow-tree, he went straight down the narrow path. As I was anxious to see the snake, I followed him. From time to time saying "it will change soon" or "it will soon become a snake," he walked on. "In time it will become one, it will become a snake, it will be sure to become one, and then the flute will play," he kept singing and walking on and, at last he came to the bank of the river. As there was no bridge nor boat, I thought he would take a rest here and show us the snake in the box, but he began to wade across the river splashing as he went. First the water was kneedeep, but gradually it came up to his waist, then to his breast, and he seemed about to disappear. But singing "The water becomes deeper, night becomes darker, my way becomes straight," he walked straight on. His moustache, his face, his head, and 
his hood disappeared. Hoping that he would show me the snake when he had landed on the opposite shore, I stood long alone where the reeds were rustling, awaiting him. But the old man did not come out of the river.

Note:-

1. Ojii-san : the term has about the force in Japanese of 'good old man.'

2. Shoji : a paper sliding-door.

3. Tabi: socks reaching just above the ankle.

4. Ameya: a wheat-gluten vendor. 
THE FIFTH NIGHT 


\section{THE FIFTH NIGHT}

\section{CUCH was my dream :-}

$\mathcal{I}$ If my memory is correct, it was an affair of far bygone times, somewhere near the age of the gods. I fought a battle and by ill luck I was defeated and taken prisoner. And I was brought before the commander of the enemy force. The people in those days were all very tall and wore long beards. From the leather belts around their waists, hung their club-like swords. Their bows were of big wistaria-vines which were used just as they grew. They were neither varnished with lacquer nor polished, but were very simple and primitive.

The enemy's general, grasping the middle of his bow with his right hand, and standing it up on the grass, was sitting upon what looked like a wine-jar upside-down. I looked up at his face and saw that his thick eyebrows came together over his nose. In those days razors were of course unknown. 
As I was a prisoner, I could not sit upon a stool. I squatted cross-legged upon the grass. I was in big straw boots. The straw boots of that age were high ones. When a man stood up they came up to his knee-cap. The upper edges of the straw boots were left unbraided so that they fluttered in the wind like tassels, when the wearer walked.

The general, by the light of a camp-fire, looked into my face, and asked which I would prefer, life or death. This was one of the customs in those days, and every prisoner, whatever his rank, was asked this question for form's sake. If one answered, saying "I will live," it was taken to mean surrender, and if one answered "I will die," it was taken to mean no surrender. I simply replied that I would die. Then the general threw away his bow which he had been holding upright on the grass, and like a flash drew out the club-like sword which had been hanging from his waist. Just then the camp-fire flickered fitfully as if it were about to be blown out by the wind. I opened my right hand spreading it out like a maple-leaf and, turning it towards the general, raised it to my eyes. This was a 
signal entreating him to wait. The general sheathed his big sword with a thud.

Love existed even in those days. I was hoping to see my loved one before I died. The general said that he would wait until day-break came with the crowing of the cocks. She had to arrive before the cock crowed. If the cock crowed and she had not come, I should be killed without seeing her. Such was my fate.

Sitting on his stool, the general gazed at the camp-fire. I sat on the grass with my straw-boots crossed.

At intervals, the sound of the collapsing camp-fire could be heard. Each time the fire fell the spurting flame leapt forward toward the general. Under his black eyebrows the general's eyes were sparkling. Then some man came to throw fresh twigs upon the fire and went away. After a while the fire snapped and cracked. The crackling sounds were high-spirited as if triumphing over the darkness.

Just at this moment, in another place a woman led out a white horse which had been tethered to an oak-tree at the back of her house. She patted it three times on the 
neck and mounted on its back like a flash. She rode bare-backed with neither saddle nor stirrups. To the animal's big paunch she gave a kick with her long white legs, and it galloped away at the top of its speed.

Someone replenished the watch-fire, and to horse and rider the distant sky seemed dimly aglow. Making straight for this glow they galloped through the darkness. The breath from the horse's nostrils was like two streams of fire as it galloped on. Still the woman spurred the creature's flanks with her slender legs. The horse went so fast that the beat of its hoofs resounded without a break in the air. The woman's hair streamed like a pennant in the dark, Even at this speed she could hardly reach ere dawn, the place where the watch-fire was burning.

Suddenly by the dark roadside, the cry of the cock was heard. The woman's body swayed backward, as she drew rein with both hands. The horse buried its front hoofs deeply in the rocky ground with a shock.

Again the cock crowed.

Struck dumb with astonishment, the woman at once slackened the rein which 
she had tightened. The horse knelt on its front legs. Then it slipped and fell forward with the woman on its back. Just below this rocky spot was a deep gulf. Into that they fell.

The hoof-prints still remain in the rock. It was an evil jester that imitated the cock crowing. As long as the hoof prints are found in the rock, that jester will be my sworn enemy. 
THE SIXTH NIGHT 


\section{THE SIXTH NIGHT}

T $\mathrm{T}$ was bruited about that Unkei ${ }^{(1)}$ was

1 carving a $\mathrm{Ni}^{(2)}$ at the front gate of the Gokokuji Temple. (3) While taking a walk, I went there and found a large crowd already assembled, making irresponsible criticisms of the sculptor's work.

About thirty or forty feet in front of the gate there stood a large red pine-tree towering into the blue sky. Its trunk, hiding the tiled roof of the gate, grew towards the blue sky. The green of the pine leaves and the vermillion-painted gate made a splendid contrast. And the pine-tree occupied a very good position. As if not to obstruct our view, its trunk, diagonally cutting off the left corner of the gate from the field of vision, extended its upper branches wider, as it soared towards the roof. About this sight there was something of the antique. I imagined myself back as in the remote Kamakura period. ${ }^{(4)}$ 
But oddly enough, all the lookers-on, like myself, were of the Meiji era. Most of them were jinrikisha-men. They were evidently standing there because they had become tired of waiting for a fare in the streets.

"What a devilishly big thing it is!" said one of them.

"It requires much more effort than to make a man, I'm sure!" said another.

While a third man exclaimed, "Oh, my, that's a Niō, isn't it? Niō are carved even now-a-days? Oh, I see. I thought all Niō were relics of the past."

"He looks very strong, doesn't he?" said a fourth man, "I've heard that in the days gone by there was nobody so strong as Niō." "At any rate," he continued, "Niō was stronger than Yamato-dake-no-Mikoto, I understand." The man's skirt was tucked up behind and he had no hat. He was evidently an uneducated man.

Unkei, quite indifferent to the irresponsible remarks of the spectators, went on working with his chisel and mallet. Not even a cursory glance did he cast at them. Standing high on a scaffold, he was intently carving at the Niō's face. 
Unkei, with a small eboshi ${ }^{(5)}$-like headgear upon his head, had the large sleeves of his garment tied up on his back, and I cannot tell whether it was a robe of the nobles of olden times or some other outer garment. His attire was very antique, and quite out of harmony with the modern noisy and jabbering crowd. I wondered how Unkei had managed to live on up to this age. Thinking it quite a mystery, I still continued to stand and gaze up at him.

As for Unkei, however, he carved on with all his might, looking as if he found nothing strange in his situation. A young man who had been gazing up at the sculptor, turned to me, saying in admiration, "As might have been expected of Unkei, he takes no notice of us at all. Just look at his attitude. He seems to think that in this wide world there is no great man but the Niō and himself. It's magnificent."

This remark I thought interesting. Therefore, I just turned a glance upon the young man, when he immediately added, "See how he uses his chisel and mallet! Really in his art he is in an exquisite inner world of omnipotence." 
Unkei had just chiselled the great inchlong eyebrows horizontally, and no sooner had he put back the chisel in its perpendicular position than he applied the mallet a little obliquely to the head. The hard wood being thus chiselled loose, a thick chip flew off in response to the sound of the mallet, and the next moment one side of an enormous nose dilated with anger appeared in relief. Boldly he employed his chisel, looking as if he had not the slightest shadow of doubt as to his skill.

"How wonderful it is that such a bold use of the chisel can carve such eyebrows and nose as he hopes for!" I said to myself in admiration. Then, the young man said, "No; he does not make the eyebrows and nose with the chisel. He only cuts out by the help of the mallet such eyebrows and nose as lie buried in the wood. That is all. It's just like digging stones out of the earth, and he can make no error."

Then for the first time, I also began to consider sculpture to be as easy an art as the young man said. Judging from what he had told me, I thought anybody could do it. A sudden desire to carve a Niō came 
to my mind, and I hurried back to my house.

Getting a chisel and an iron hammer from the tool-box, I went out to the backyard, and found a pile of good-sized logs which I had had prepared for fire-wood by a sawyer from an oak blown down by a recent storm. Selecting the largest piece, I began to carve spiritedly, but unfortunately had no success in finding a Niō. With a second $\log$ I was no more fortunate.

A third one also contained no Niō. I tried, one after another, all the logs which had been piled up there, but none of them had a Nio concealed in it. At last I came to the conclusion that in no wood of the Meiji era were Niō buried. And thus I felt I understood why Unkei had lived to this day.

Note:-

1. Unkei is a famous sculptor who lived in the twelfth century. Little is known about his boyhood. Winning great fame by carving a Buddha's image in 1164 together with his 
father, he turned out several works of permanent artistic value before his death in 1176.

2. Nio are the figures of the two giants guarding the entrance of Buddhist temples in Japan.

3. Gokokuji temple stands in Koishikawa-ku, Tokyo.

4. Kamakura period, when Japan attained a high standard of culture, continued from 1180 until 1333.

5. Eboshi is an ancient ceremonial cap resembling a hood in shape. 

THE SEVENTH NIGHT 


\section{THE SEVENTH NIGHT}

SOMEHOW I was aboard a big ship. $\mathcal{O}$ Day and night the boat continually sent up black smoke and went ahead cleaving the waves. It made a terrible din. But I did not know where it was bound for. Only I saw the sun resembling a redhot steel rod rise from beneath the waves. It seemed to be hanging aloft for a while after arriving above the high mast, but it would go ahead and leave the ship behind before I was aware. And finally it would sink under the waves with a hiss like a red-hot steel rod plunged into water. Every time it went down, the blue waves in the far distance would take the colour of suho. ${ }^{(1)}$

Once I asked one of the crew, "Where is this boat bound for?" The man gazed at me for a while with a puzzled look, and then asked back, "Why?" 
"Well, because it seems as if the boat were running after the sinking sun," I explained.

The man laughed aloud, and went away, singing :

"When the sun moves west-

Is it bound east?

I wonder?

When the sun rises east-

Is its home in the west?

I wonder?

We lie on the waves,

Our head on the helm,

Lets go drifting and drifting along."

I went to the bow, and found a number of sailors hauling in a heavy rigging rope.

I felt very lonely. I did not know where I should be able to go ashore. Nor did I know where I was going. That the ship sent up black smoke and went ahead cleaving the waves was the only thing which I knew for certain. The sea was very vast. It was an infinite expanse of blue. Sometimes it took on a purple colour. Only the waves around the moving ship were always foaming white. I 
was very lonely. I even thought of ending my life by jumping overboard rather than remain on board such a ship.

Of my fellow-passengers there were many. Most of them apparently were foreigners. But they were of widely varying types. Once when the boat pitched and rolled with a lowering sky overhead, I found a woman leaning against the railing, weeping copiously. I noticed the whiteness of the handkerchief with which she wiped her tears. She wore a dress of what looked like print. Seeing this woman, I realized that I was not the only sad soul.

One night I went out on deck, and while I was gazing at the starry sky, a foreigner walked up and asked me if I knew astronomy. I was so lonely as to think of dying. What would it profit me to know astronomy? I did not speak. None the less the foreigner told me a story about the Golden Cow, saying that the stars and the sea were all made by God. At the end, he asked me if I believed in God. I looked up at the sky but did not speak.

Once I walked into the lounge and saw a gaily-dressed young woman playing on the 
piano with her back to the entrance. By her side, a tall, good-looking man was standing, singing to the accompaniment of the piano. His mouth looked unusually big. These two persons did not seem to care a bit about anything but themselves. They even seemed to be unaware that they were in a boat.

I felt more desolate than ever. Finally, I made up my mind to die, and one night, when there was no one about, I resolutely jumped overboard.

But, alas, the instant my feet left the deck and I knew I was no more aboard the ship, I suddenly felt reluctant to die. Sincerely I regretted what I had done. But it was too late. I had to go down into the sea. However, probably because of the unusual height of the hull, my feet did not strike water too quickly. There being nothing to clutch at, I went down and down toward the water. Hard though I tried to draw up my legs, I was getting nearer and ever nearer to the black-looking water.

In the meanwhile, the ship had passed along, sending up its usual black smoke. It now occurred to me for the first time that it 
would have been better for me to have remained aboard in spite of the fact that the boat was bound no one knew where, but, this thought availing nothing, I continued to go down and down slowly towards the black waves with a sense of unbounded remorse and fear.

Note:-

1. Suho: a plant known scientifically as Caesalpinia sappan. 
THE EIGHTH NIGHT 


\section{THE EIGHTH NIGHT}

T CROSSED the threshold of a barber's 1 shop, and three or four men in white greeted me in chorus. I stood in the centre of the place and, looking about, I saw it was a square room. There were windows on two sides, and the remaining two walls had mirrors on them. I counted the mirrors which were six in number.

I sat down in front of one of the mirrors. I felt some gently yielding springs under me. The chair was so well-made that it was very comfortable to sit on. The mirror gave a splendid reflection of my face. Behind my face in the mirror a window was in sight. A lattice enclosure for the cashier was also visible obliquely. There was nobody in the enclosure. I could clearly see the upper halves of the passers-by in the street through the window in the mirror.

Shotaro walked past with a woman. He wore a panama hat, which he must have 
bought without my noticing it before. When he made the acquaintance of the woman was also something of a mystery. Both seemed proud of each other. I wanted to see the face of the woman well, but they were out of sight before I could do so.

A bean-curd vendor hurried past, blowing his horn. With horn in mouth, his cheeks were blown out as if they had been stung by bees. As he passed on with his cheeks blown out, I could not help feeling uneasy about him. I felt afraid lest he should look as if he had been stung by bees all the rest of his life.

Next came a geisha. Her toilette was yet to be made. The bottom knot of her shimada ${ }^{(1)}$ had become loosened and her hair as a whole looked somewhat untidy. She was looking sleepy, too. Her face was pitifully colourless. She bowed and murmured a greeting to some one, who did not appear in the mirror at all.

Then a big man in white came up and stood at my back and began looking at my hair with scissors and comb in hand. Twisting one end of my thin moustache, I asked him if it would grow thick. Saying nothing 
in reply, the man in white stroked my hair with his amber coloured comb.

"Well, apart from the question of my hair, what do you think of my moustache!" I asked again of the man in white, "Will it grow?"

Still giving no answer, the man in white began clicking his scissors.

Desiring to see all that would be reflected in the mirror, I kept staring hard, but a cluster of black hair would come flying at each click of the scissors, which made me timid, and soon I closed my eyes. Then the man in white asked:

"Did you see the goldfish man outside, sir?"

I told him that I had not. The man in white spoke no more, and busied himself with the clicking scissors.

"Look out!" some one cried out all of a sudden.

I opened my eyes quickly and saw a wheel of a bicycle under one of the sleeves of the man in white. The shafts of a jinricksha came in sight, too. At that moment the man in white seized my head with both 
hands and turned it round. The bicycle and the jinrikisha went out of view altogether. The scissors continued clicking.

After a while, the man in white stepped round to my side and began clipping the locks around one of my ears. As the clipped hair ceased to fly forward, I felt relieved and opened my eyes. A voice hawking awamochi ${ }^{(2)}$ sounded close by me. Mochi was being pounded, a small pestle beating time on a wooden mortar every now and then. As I had not seen an awamochi vendor since my boyhood, I wanted to see again what he looked like. But the awamochi vendor would not appear in the mirror. I could only hear the sound of his mochi being pounded. I stared into the mirror, with all my might and I saw a woman kneeling in the cashier's lattice enclosure, although I did not know when she had appeared there.

A little dark in colour, she was rather big in build and had thick eyebrows. With her hair done up in ichogashi, ${ }^{(3)}$ she wore a piece of awase ${ }^{(4)}$ next to her skin, without underwear. She was counting bank notes in her kneeling posture with one of her 
knees raised a little. The notes seemed to be all of $¥ 10$. With her long eyelashes down and her thin lips firmly closed, she was absorbed in her counting which she did at an amazing speed. But there apparently was no end of her counting. The notes on her lap were only about one hundred in number at the most, but she seemed unable to finish counting them, however long she might continue.

Absentmindedly I gazed on at the face of the woman and the $¥ 10$ notes until the man in white shouted in my ears, "Hair wash, sir!"

Given a good chance, I looked back towards the lattice enclosure as soon as I stood up. But I saw neither the woman nor the notes within the enclosure.

Having paid, I walked out and found some five oval tubs displayed on the left side of the entrance, in which I saw a large number of goldfish, some red, some spotted, some thin, some fat. And I saw the goldfish vendor beside them. The goldfish vendor was sitting still with his cheeks supported by both his hands, gazing at the 
goldfish displayed in front of him. He paid little or no attention to the bustle of the street. I stood for a while, looking at him. But he did not even stir.

Note:-

1. Shimada is a style of coiffure for the younger geisha and downtown girls.

2. Awamochi is steamed millet pounded into dough, eaten with bean-jam.

3. Ichogaeshi is a style of coiffure for the older geisha and downtown cafe waitresses.

4. Awase is a lined garment, not quilted. 

THE NINTH NIGHT 


\section{THE NINTH NIGHT}

U

NEASINESS began to prevail everywhere. Civil war seemed imminent. It seemed as if unsaddled horses, bolting away from their stables during a fire, were running wild around the house day and night, sought after by noisy stable-hands. Nevertheless profound quiet reigned inside the house.

In the house there were a young mother and a two-year-old child. The father had gone away, nobody knew where. It was at midnight, when there was no moon out, that the father had gone away. Sitting on his bed, he had put on a pair of waraji, ${ }^{(1)}$ slipped on a black hood and walked out from the kitchen door. The paper lantern the mother was then holding threw a long stream of faint light in the darkness and shone on the old Japanese cypress tree standing inside the hedgerow. 
The father never came back. The mother would ask her two-year-old child day after day where his father was. The child would not speak. After a while the child learned to answer, "Over there." Even if asked by his mother when his father was coming back, the child would keep smiling, saying, "Over there." Hearing it, the mother would smile, too. And she would try to teach the child to say, "He will be back by and by." But the child only learned to say "by and by." Sometimes he would reply, "By and by," when asked where his father was.

When night came and it became quiet all around, the mother would make sure that her sash was tied securely and, thrusting a dagger under the sash, would walk out noiselessly through a side gate with the child slung on her back in a narrow sash. The mother used to wear straw sandals. The child sometimes would go to sleep on his mother's back while listening to the pattering of her sandaled feet.

Going down west along the street, which was lined with the mud fences of samurai's houses, one came to a big maiden-hair tree 
at the foot of a slight slope. Turning to the right with the maiden-hair tree as the turning point, there was a stone torii ${ }^{(2)}$ about a hundred yards away. Walking down the road, which passed between paddyfields on one side and a piece of land overgrown with nothing but bamboo grass on the other as far as the torii, one passed under it to find oneself in a dark grove of cryptomeria. Farther on, a stone-paved path led for about forty yards to the staircase of an old worship-hall. There hung down a cord attached to a big bell above an offertory box, which was already grey with washing. In daylight one could see the framed name-plate of the shrine set up beside the bell, reading "Hachi-mangu." It was interesting to see the character "hachi" which looked like two pigeons facing each other. There also were various framed offerings. Many of them consisted of golden targets, framed together with the signatures of the feudal archers who had hit them. A few other frames contained swords.

On passing through the shrine gate, the child would always hear the hooting of owls in the cryptomeria trees. And the 
pattering of his mother's straw sandals would become clearer and clearer. When they stopped in front of the worship-hall, the mother would first of all ring the bell, and immediately crouch down and clap her hands. Usually at this the owls would stop hooting suddenly. Then the mother would forget herself in praying fervently for the safety of her husband. As her husband was a samurai, the mother was convinced that there was no reason why Hachiman, the God of the Bow and Arrow, should not answer the prayer she offered with so great a faith.

The child would sometimes be awakened by the ringing of the bell and, seeing darkness all around, cry out suddenly on his mother's back. Then the mother would try to soothe him by rocking him gently on her back without ceasing to murmur her prayer. Sometimes she would succeed in making the child stop crying. But it would also happen that the child cried more violently than ever. In either case, the mother would not stand up readily.

When she finished saying all that she had to say in her prayer for the safety of her 
husband, the mother would unfasten the narrow sash securing the child, and pulling him down from her back, she would take him into her arms and step up into the worship-hall. Then she would press her, cheek to that of her child and say, "there's a good boy! Wait here just a little while, will you." Then straightening out the narrow sash, she would tie the child with it and fasten its other end to the railing of the worship-hall. After that, she would step down the staircase and begin the rite of $O$ hyakudo ${ }^{(3)}$ along the forty-yard stone-flagged path.

Tied to the railing of the worship-hall, the child would sometimes keep crawling about quietly on the floor as far as the sash would permit, to the great relief of the mother. But when the child in captivity cried violently, his mother could not feel at ease even for a second. Her step would be greatly quickened. She would breathe hard. When it became unbearable, she would stop short, return to the worship-hall and, after doing her best to soothe her child, would begin the rite of O-hyakudo on the stoneflagged path all over again. 
The father, for the safety of whom the mother worried so deeply and passed so many sleepless nights, had been murdered by some ronin ${ }^{(4)}$ long before.

This sad story I heard from my mother in a dream.

Note:-

1. Waraji is a sort of straw sandal for the use of travelers, secured to the foot by two straw cords.

2. Torii is a shrine gate, consisting of two poles and two cross beams.

3. O-hyakudo is a rite of making one hundred trips along a certain length of path at a shrine or temple.

4. Ronin is a samurai not in regular service under any feudal lord. 

THE TENTH NIGHT 


\section{THE TENTH NIGHT}

WEN-SAN came to tell me that on the 1 seventh day after Shotaro had been led away by a woman, he came back absentmindedly and was stricken with a sudden bout of fever.

Shotaro was the best-looking man in our neighbourhood, and very good-natured and honest, too. He had only one weakness. When evening came on, he would sit on the edge of the counter of the fruit-store, wearing a panama hat, and keep looking at the faces of the women who came along. He was busy admiring them. He had no other weakness to speak of.

When there were not many women coming along, he would look at the fruits. Peaches, apples, loquats and bananas were arranged to beautiful effect in baskets, which were displayed in two rows, ready to be taken away as presents. Shotaro admired these baskets of fruit, and used to say 
he would prefer the trade of a fruit-store keeper to any other. Nevertheless, he simply kept loafing about in his panama hat.

Sometimes he made comments on oranges and other fruits, saying that he liked this colour or that. But he had never paid a copper for fruit. Nor did he condescend to eat any which was not paid for. He simply went on admiring the colours of the fruits.

One evening a woman suddenly appeared in front of the store. She was well dressed, apparently of some social standing. The colour of her kimono pleased Shotaro immensely. Moreover, he was struck with the beauty of her face. Therefore, he took off his much valued panama hat and greeted her respectfully. Pointing to the largest basket of fruits, she said she wanted it. So, taking up the basket quickly, Shotaro handed it to the lady, who held it in her hand just a little while and said it was very heavy.

Having no particular business to attend to and moreover being quite light-hearted, Shotaro offered to take the basket to the home of the lady, and left the fruit-store with her. 
Carefree though he was, Shotaro could not afford to be so easygoing as that. Fearing lest there was something wrong with him, his relatives and friends were beginning to feel anxiety over his safety, when on the seventh day he came back absentmindedly.

Surrounded by many people and asked where he had been all the while, Shotaro replied that he had ridden in an electric car to a mountain.

It seemed that he had quite a long ride in the car. According to his own story, Shotaro came upon a heath immediately after getting off the car. It was a very vast field and there was nothing to be seen but grass on all sides. While walking on the grass with the woman, he suddenly found himself on the edge of a precipice. Then the woman told Shotaro to jump down.

Looking down into the abyss, he saw the steep face of the cliff but there was no bottom visible. Shotaro took off his panama hat and politely declined the command repeatedly. Thereupon, the woman asked him if he was ready to be licked by sows in case he failed to make up his mind to jump down. Sows and Kumoyemon ${ }^{(1)}$ were what Shotaro 
hated most. But thinking that it would be better to meet some sows than to die, he decided not to jump down. Then a sow came up sniffing. As a last resort Shotaro struck it on the snout with his thin stick of palm. The sow groaned, rolled over and fell down the precipice. Shotaro had hardly heaved a sigh of relief than another pig came up, pressing its big nose against him. Shotaro could do nothing but brandish his stick. The pig groaned and rolled head first down the abyss. Then there appeared another pig. At this moment Shotaro suddenly realized what he was up against and looked beyond to find an infinitely large herd of pigs, tens of thousands in number, snuffling and coming on straight towards him as he stood at the edge of the cliff far from the other end of the moor. Shotaro felt completely at a loss, But as there was nothing else to do, he went on carefully striking the snouts of the oncoming pigs one by one with great dexterity. Strange to say, no sooner had the stick touched its nose than each pig would immediately roll down the abyss. Looking down, he saw an endless row of pigs falling headlong down the cliff. Shotaro shuddered in spite of himself to think that he 
had made so many pigs roll down into the abyss. But the pigs would not cease to come on. They came sniffing endlessly as though the herd had been a black cloud provided with countless legs to walk up on the green grass.

Shotaro mustered all the courage that was in him and kept striking the pigs' snouts for seven days and six nights on end. But at length he was exhausted with his arms becoming as limp as konnyaku ${ }^{(2)}$ and he was licked by the pigs after all. He collapsed on the edge of the cliff.

Ken-san related Shotaro's story thus far, and said that for this reason it would not be well to look at women too much. I agreed. Ken-san said he would like to have Shotaro's panama hat. Shotaro will not live. Ken-san will get his panama hat.

\section{Note:-}

1. Kumoyemon was a famous Naniwabushi reciter, a blend of minstrel and story-teller.

2. Konnyaku is a paste made from the starch of the devil's tongue, a common food in Japan. 


\section{OUR CAT'S GRAVE}




\section{OUR CAT'S GRAVE}

$A \begin{aligned} & \text { FTER we removed to Waseda our cat } \\ & \text { began to grow lean and lank. She did }\end{aligned}$ not seem to want to join the children in frisking about at all. When the sun shone, she would go to sleep on the verandah. Stretching her front legs out straight, she would put her square chin down on them, and, fixing her eyes on the plants in the garden, would not move for hours. No matter how noisily the children might play about her, she did not seem to be at all disturbed.

As to the children, they practically refused to associate with their old friend whom they treated like a stranger, as much as to say, "This kittie isn't friendly enough for a playmate."

Not only the children but also our maidservant cared little for Puss: she took the trouble to put the three meals for the poor animal in a corner of the kitchen but would do nothing else. 
The three meals, however, were usually made away with by a big and thievish tabby-cat of the neighbourhood before our cat had touched them. She did not even appear to get angry at this, and never quarreled. She slept quietly all the time.

But her manner of sleeping was without freedom or ease. She did not lie comfortably and enjoy the pleasant sunshine. It seemed she could not afford to move but this is not sufficient to describe her state. In other words she found life exceedingly dull and she knew that she could not shake off this feeling without moving, but to move would make her feel more lonely. She seemed to have decided to lie still and put up with her surroundings.

Her eyes were ever upon the plants in the garden, but she was probably entirely unconscious of the shapes of the leaves and of their stalks. She lay with her vacant bluish-yellow eyes rivetted upon some spot.

Just as the children, her former playmates, did not seem to recognize her existence, she herself did not seem to recognize the very existence of the world around her. Sometimes, however, she would go out, 
like one who had business to attend to. On these occasions she was invariably driven home by the same tom-cat of the neighbourhood, and, terror-stricken, she would spring upon the verandah, break her way through one of the closed paper doors and rush to the hearthside.

It was only at these times that the family were reminded of her existence and that she seemed to feel any satisfaction in realizing that she was still alive.

After several repetitions of this experience, the hair on her tail grew thinner little by little. At first the hair dropped out in several spots leaving small hole-like patches. These patches grew larger till her whole tail was bare. Later on it hung down like a piece of rope.

Utterly tired of all things, she began to lick the affected parts. "My dear, I'm afraid there must be something wrong with the cat," said I to my wife.

"Perhaps so;" said she quite indifferently, "perhaps it's due to her advanced age." So after this I too left the wretched animal in her pitiable plight.

Then after a few days I noticed that the poor cat was throwing up everything she 
ate. Moving the forepart of her neck with a wavy motion she gave a mournful sound which was something between a sneeze and a hiccup. Pitiable as she looked, I could not help her. So every time I found her in this awkward situation, I thought I would drive her out.

Otherwise she would go on spoiling the mats and cushions without compunction. Most of the hattan ${ }^{(1)}$ silk cushions used for visitors had already been spoiled by her.

"This won't do," I said to my wife. "She has some kind of stomach trouble, I suppose. Dissolve some hōtan ${ }^{(2)}$ in water and give it to the poor beast."

But she did not deign to answer. A few days later, I asked her if she had given the cat any hötan and she replied: "Why, my dear, I've tried in vain to make her take the medicine, but she would not open her mouth." "As you see, even when we give her fishbones, she vomits." She added explanatorily.

"All right, then you had better not give her any," said I crossly, returning to my book.

No sooner had the cat got rid of her nausea than she slept quietly. 
Lately she had shrunk into herself in an uncomfortable way and appeared to feel that she had no place to go except the verandah upon which she slept.

Some change was visible in the expression of her eyes. First they looked as if they were fixed on some distant object brought suddenly into the near field of her vision and there was something calm about her eyes even in the midst of her wretchedness. But then they began to move in a strange way. The fire of her eyes, however, sank lower and lower like sheet lightning after a summer sunset.

However, I left her just as she was. My wife also did not seem to care for the poor creature. The children had long ceased to think of their former pet, of course.

One evening she was lying on her stomach at the foot of one of the children's beds, when, all at once she gave a deep growl such as she used to do when some one tried to seize her fish.

I was the only one who thought it very strange at the time. The children were sound asleep. Their mother was busy sewing. 
After a while the cat uttered another growl. At last my wife dropped her work. "What's the matter with the cat?" I cried. "It would be terrible if the cat should bite our children during the night."

"Nonsense!" said she, resuming her sewing on the sleeves of an undershirt. The cat growled again at intervals.

The next day, the poor creature lay down on the edge of the hearth and mewed all day long. That seemed some what repulsive to us when we went there for the tea kettle or to make tea. But when it was evening my wife as well as myself forgot all about the cat. That night the cat died. The next morning when the maid-servant went to the backyard shed to fetch some firewood, it was already lying stiff on an old kitchen stove.

My wife took the trouble of going there to see the body of the poor creature. Thereupon, her former indifference was gone and she suddenly began making a great fuss about it. She sent for our rickshaman, and getting him to buy an oblong grave-post, she asked me to write something on it. I wrote: "In Memory of A Cat" on its front 
and "Konoshitani, Inazuma okoru yoi aran," (3) on its back. The rickshaman wanted to know if he might bury the cat as it was, and the maid-servant added that she could not think of cremating it.

The children also began to make much of the cat again suddenly. They planted two glass bottles, one on each side of the gravepost, and filled them with twigs of blossoming hagi. ${ }^{(4)}$ They filled a cup with water and placed it before the grave. The flowers and the water were changed every day. In the evening on the third day, my three-yearold daughter-I was watching her through a window of my study - walked up to the grave all alone, and after gazing at the plain-wood grave-post a while, put out her toy dipper, scooped up water from the cup which was offered to the cat, and drank it. That was not the only time she did so. The water strewn with the fallen petals of hagi flowers often served to cure the thirst of little Aiko in the evening quiet.

On each death-anniversary of the cat, my wife has made it a rule to offer a small slice of salted salmon and a bowl of rice with dried bonito shavings on it before the grave. 
She has never forgotten to do so even until now. Only she seems to have come recently to place them on top of the wardrobe in her sitting room instead of walking out into the garden with them.

Note:-

1. Hattan is a kind of silk cloth.

2. Hōtan is a patent medicine.

3. Kono shitani ... This 17 -syllable verse literally reads "Underneath here, lightning may occur when it is dusk." The following are the two other translations now available;

"Sleeping here underground, Thou wilt show the gloaming, by flashing lightning."

"Here sleeps the poor cat, yet who knows but that some evening her eyes may yet glare forth again."

4. Hagi is a plant blooming in autumn, known scientifically as Lespedeza bicolor.

\section{THE END}


